European

Urology

\title{
Strategies for the Chemoprevention of Prostate Cancer
}

Symposium, October 29-31, 1998, Brussels, Belgium

Editors

C.C. Schulman, Brussels, Belgium

G.J. Kelloff, Bethesda, Md., USA

61 figures, 21 in color and 61 tables, 1999 
S. Karger

Medical and Scientific Publishers Basel $\cdot$ Freiburg $\cdot$ Paris $\cdot$ London New York $\cdot$ New Delhi $\cdot$ Bangkok Singapore $\cdot$ Tokyo $\cdot$ Sydney
Drug Dosage

The authors and the publisher have exerted every effort to ensure that drug selection and dosage set forth in this text are in accord with current recommendations and practice at the time of publication. However, in view of ongoing research, changes in government regulations, and the constant flow of information relating to drug therapy and drug reactions, the reader is urged to check the package insert for each drug for any change in indications and dosage and for added warnings and precautions. This is particularly important when the recommended agent is a new and/or infrequently employed drug.
All rights reserved.

No part of this publication may be translated into other languages, reproduced or utilized in any form or by any means, electronic or mechanical, including photocopying, recording, microcopying, or by any information storage and retrieval microcopying, or by any information storage and retrieval system, without permission in writing from the publisher or, in
the case of photocopying, direct payment of a specified fee to the case of photocopying, direct payment of a specified fee to
the Copyright Clearance Center (see 'General Information').

(C) Copyright 1999 by S. Karger AG,

P.O. Box, CH-4009 Basel (Switzerland)

Printed in Switzerland on acid-free paper by

Druckerei Schüler AG, Biel

\section{KARGER}

Fax+41613061234

E-Mail karger@karger.ch

www.karger.com 


\section{European Urology}

341 Introduction

Schulman, C.C. (Brussels); Kelloff, G.J. (Bethesda, Md.)

342 Chemoprevention of Prostate Cancer: Concepts and Strategies

Kelloff, G.J.; Lieberman, R.; Steele, V.E.; Boone, C.W.; Lubet, R.A.; Kopelovitch, L.; Malone, W.A.; Crowell, J.A. (Bethesda, Md.); Sigman, C.C. (Mountain View, Calif.)

Genetic and Environmental Factors in Prostate Cancer Genesis

351 Molecular Biology of Progression of Prostate Cancer

Nupponen, N.; Visakorpi, T. (Tampere)

355 Androgen Metabolism and Prostate Cancer: Establishing a Model of Genetic Susceptibility

Ross, R.K.; Coetzee, G.A.; Pearce, C.L.; Reichardt, J.K.V.; Bretsky, P. (Los Angeles, Calif.); Kolonel, L.N. (Honolulu, Hawaii); Henderson, B.E. (Los Angeles, Calif.); Lander, E.; Altshuler, D.; Daley, G. (Boston, Mass.)

362 Genetic and Environmental Factors in Prostate Cancer Genesis: Identifying High-Risk Cohorts

Ekman, P. (Stockholm)

370 Epidemiology of Prostate Cancer Chemoprevention Boyle, P.; Severi, G. (Milan)

377 Diet and Its Preventive Role in Prostatic Disease Denis, L. (Antwerp); Morton, M.S.; Griffiths, K. (Cardiff)

388 Dietary Fat and Prostate Cancer Progression and Survival Fradet, Y.; Meyer, F.; Bairati, I.; Shadmani, R.; Moore, L. (Québec)

Molecular Targets for Chemoprevention of Prostate Cancer

392 Vitamin D and Prostate Cancer Risk

Peehl, D.M. (Stanford, Calif.)

395 Lipoxygenase Inhibition in Prostate Cancer Myers, C.E.; Ghosh, J. (Charlottesville, Va.)

399 Angiogenesis, p53, bcl-2 and Ki-67 in the Progression of Prostate Cancer after Radical Prostatectomy

Moul, J.W. (Washington, D.C./Bethesda, Md.)

408 Changes in Gene Expression and Targets for Therapy Bussemakers, M.J.G. (Nijmegen)

413 Mechanism of Androgen Receptor Activation and Possible Implications for Chemoprevention Trials

Klocker, H.; Culig, Z.; Eder, I.E.; Nessler-Menardi, C.; Hobisch, A.; Putz, T.; Bartsch, G. (Innsbruck); Peterziel, H.; Cato, A.C.B. (Karlsruhe)

420 New Agents for Chemoprevention of Prostate Cancer Sporn, M.B. (Hanover, N.H.)

424 Retinoids in Chemoprevention Whelan, P. (Leeds)

429 Evaluation of Biomarker Modulation by Fenretinide in Prostate Cancer Patients Urban, D.; Myers, R.; Manne, U.; Weiss, H. (Birmingham, Ala.); Mohler, J. (Chapel Hill, N.C.); Perkins, D.; Markiewicz, M. (Birmingham, Ala.); Lieberman, R.; Kelloff, G. (Bethesda, Md.); Marshall, M.; Grizzle, W. (Birmingham, Ala.)

439 Factors Controlling the Expression of $5 \alpha$-Reductase in Human Prostate: A Possible New Approach for the Treatment of Prostate Cancer Habib, F.K.; Ross, M.; Bayne, C.W. (Edinburgh)

443 Certain Aspects of Molecular Endocrinology That Relate to the Influence of Dietary Factors on the Pathogenesis of Prostate Cancer Griffiths, K.; Morton, M.S. (Cardiff); Denis, L. (Antwerp)

Preclinical Models for Drug Discovery

456 High-Grade Prostatic Intraepithelial Neoplasia in Dogs Waters, D.J. (West Lafayette, Ind.)

\section{KARGER}

Fax+41613061234 E-Mail karger@karger.ch www.karger.com
(C) 1999 S. Karger AG, Basel

Access to full text and tables of contents, ncluding tentative ones for forthcoming issues: www.karger.com/journals/eur/eur_bk.htm 
459 Use of Animal Models in Defining Efficacy of Chemoprevention Agents against Prostate Cancer

Bosland, M.C. (New York, N.Y.)

464 Chemoprevention of Hormone-Dependent Prostate Cancer in the Wistar-Unilever Rat McCormick, D.L.; Rao, K.V.N. (Chicago, Ill.)

Surrogate Endpoint Biomarkers for Clinical Trials of Prostate Cancer Chemoprevention

468 Subtle Morphological and Molecular Changes in Normal-Looking Epithelium in Prostates with Prostatic Intraepithelial Neoplasia or Cancer

Montironi, R. (Ancona); Hamilton, P.W. (Belfast); Scarpelli, M. (Ancona); Thompson, D.; Bartels, P.H. (Tucson, Ariz.)

474 Prostatic Intraepithelial Neoplasia: A Marker for High-Risk Groups and a Potential Target for Chemoprevention

Sakr, W.A. (Detroit, Mich.)

479 Genetic and Chromosomal Alterations in Prostatic Intraepithelial Neoplasia and Carcinoma Detected by Fluorescence in situ Hybridization Qian, J.; Jenkins, R.B.; Bostwick, D.G. (Rochester, Minn.)

484 Tissue Architecture Analysis in Prostate Cancer and Its Precursors: An Innovative Approach to Computerized Histometry

Bartels, P.H. (Tucson, Ariz.); Montironi, R. (Ancona); Duval da Silva, V. (Brasília/Porto Alegre); Hamilton, P.W. (Belfast); Thompson, D.; Vaught, L.; Bartels, H.G. (Tucson, Ariz.)

492 Reversibility of Prostatic Intraepithelial Neoplasia: Implications for Chemoprevention Bostwick, D.G.; Neumann, R.; Qian, J.; Cheng, L. (Rochester, Minn.)

496 Evolution of Isolated High-Grade Prostate Intraepithelial Neoplasia in a Mediterranean Patient Population

Algaba, F. (Barcelona)

498 Clinical Evolution of Prostatic Intraepithelial Neoplasia Zlotta, A.R.; Schulman, C.C. (Brussels)

504 PIN I-III: When Should We Interfere? Newling, D. (Amsterdam)

508 Prostatic Intraepithelial Neoplasia and Endocrine Manipulation van der Kwast, Th.H.; Labrie, F.; Têtu, B. (Rotterdam/Québec)

511 The Utility of Prostate-Specific Antigen as a Surrogate Marker for Identification of HighRisk Cohorts and Assessing Response in Chemoprevention Trials Crawford, E.D. (Denver, Colo.)

Clinical Trial Designs for Chemoprevention of Prostate Cancer

515 Practical Aspects of Clinical Trials on Chemoprevention of Prostate Cancer van der Meijden, A.P.M. ('s-Hertogenbosch)

519 Statistical Considerations of Chemoprevention Clinical Trials in Prostate Cancer Sylvester, R.; Collette, L. (Brussels)

523 Prostate Cancer Screening in Tyrol, Austria: Experience and Results Horninger, W.; Reissigl, A.; Rogatsch, H.; Volgger, H.; Studen, M.; Klocker, H.; Bartsch, G. (Innsbruck)

539 The European Randomized Study of Screening for Prostate Cancer (ERSPC): An Update Schröder, F.H.; Kranse, R.; Rietbergen, J.; Hoedemaeker, R.; Kirkels, W. (Rotterdam); and members of the ERSPC

544 Prostate Cancer Prevention Trial (PCPT) Update

Coltman, C.A., Jr.; Thompson, I.M., Jr. (San Antonio, Tex.); Feigl, P. (Seattle, Wash.)

354, 423 Congress Calendar

548 Author Index Vol. 35, No. 5-6, 1999

549 Subject Index Vol. 35, No. 5-6, 1999

550 Forthcoming Papers

551 Acknowledgement to the Reviewers

552 Author Index Vol. 35, 1999

554 Subject Index Vol. 35, 1999

after 556 Contents Vol. 35, 1999

Curriculum in Urology 2.4

Infections and Stones

Prostatitis and Urethritis

Ludwig, M.; Weidner, W. (Giessen) 